\title{
Spectral characteristics of Common Iora Aegithina tiphia vocalizations and their context-specific preferences
}

\author{
C. Divyapriya ${ }^{1,2, *}$ and P. Pramod ${ }^{1}$ \\ ${ }^{1}$ Sálim Ali Centre for Ornithology and Natural History, Anaikatty (P.O.), Coimbatore 641 108, India \\ ${ }^{2}$ Bharathiar University, Marudhamalai Road, Coimbatore 641 046, India
}

Spectral properties such as duration of signal and frequency range were studied in Common Iora Aegithina tiphia vocalizations. Bird calls were sampled from different locations of the study area at different times to capture variability of their vocal signals in space and time. Along with call recordings, behaviour parameters such as presence of male or female conspecific members and their activities were recorded. From 48 bird call data, a total of $240 \mathrm{~min}$ of recordings was analysed. The most commonly uttered 15 syllables were identified, of which 14 were produced by males and the remaining one by females. Basic statistics of the spectral characteristics along with the observed behavioural parameters explain the natural history of Common Iora. The duration of syllable and frequency parameters such as low and high frequencies varied significantly across the 15 syllables. Common Iora males were recorded as using high frequency syllables with shorter duration as 'contact calls' with the nearby conspecific members, while low frequency 'long distance' calls were used by solitary males. Though these context preferences are not conclusive in nature based on this brief study, it suggests existence of context specificity of spectral characteristics in bird vocalizations.

Keywords: Acoustic parameters, bird acoustics, call syllable, Common Iora, frequency range.

CALL repertoire of bird songs is of considerable interest. Baseline information about the syllables, their spectral characteristics and contextual preferences is important for any detailed study of songbirds. Time duration, element composition, frequency bandwidth, harmonic structure and noisiness are biologically significant spectral traits of bird vocalization. Birds respond to these temporal and spectral structures of sound ${ }^{1}$. The fundamental units of the vocal spectrum of a bird, 'elements' combine to form a syllable ${ }^{2}$. The quantitative characteristics of a syllable can be viewed by scrolling across the spectrogram ${ }^{3,4}$. This yields quantitative comparisons of visually represented signals and hence, is the advantageous and preferred

*For correspondence. (e-mail: cdp08india@gmail.com) mode of bioacoustic analysis ${ }^{1,5-9}$. Spectrogram visualization is used to measure individual notes or the entire call sequence ${ }^{4}$.

The vocal signal of birds comprises monotonic 'syllables' with uniform frequency range $^{1}$ or frequency modulated (FM) syllables. Syllable repertoire of birds contains 'trills' (wide frequency ranged signals) and 'whistles' (smaller amplitude of variation).

The forest bird species broadcast low frequency syllables for long distance transmission ${ }^{10,11}$. (i) in open habitats $^{12}$, (ii) in temperate forest and grassland habitats $^{13}$, (iii) on tilled ground ${ }^{14}$ and (iv) in tropical monsoon forest, thick undercover habitat and tropical forest edges $^{15}$. The FM signals are avoided in habitats with signal scattering surfaces, such as leaves and branches ${ }^{10}$.

Exploration of bird calls for their varied syllables, characterization of spectral features and time duration of delivery of the calls are analysed in this study.

\section{Study species}

Common Iora Aegithina tiphia, the selected study species is a tropical scrub jungle and dry deciduous forest species, generally seen in pairs ${ }^{16}$ (Figure 1). The birds forage by gleaning on the barks and leaves ${ }^{17}$. They are extremely agile and display acrobatic poses during feeding ${ }^{16}$. Their breeding season extends from January to August ${ }^{16}$. Both the male and female vocalize frequently ${ }^{16}$ and produce short syllables that are repeated consecutively (pers. obs.).

\section{Study area}

The study area, viz. Anaikatty hills $\left(11^{\circ} 05^{\prime} \mathrm{N}, 76^{\circ} 47^{\prime} \mathrm{E}\right)$, Coimbatore district, Tamil Nadu, India (Figure 2) is a part of the Nilgiri Biosphere Reserve (NBR). It is approximately $500-600 \mathrm{~m}$ asl and experiences temperature varying from $17^{\circ} \mathrm{C}$ to $36^{\circ} \mathrm{C}$ (ref. 18). The study site is on the leeward side of the Western Ghats and receives an average annual rainfall of about $700 \mathrm{~mm}$, which is mainly contributed by the northeast monsoon. The study site is a secondary forest surrounded by dry deciduous forest rich 


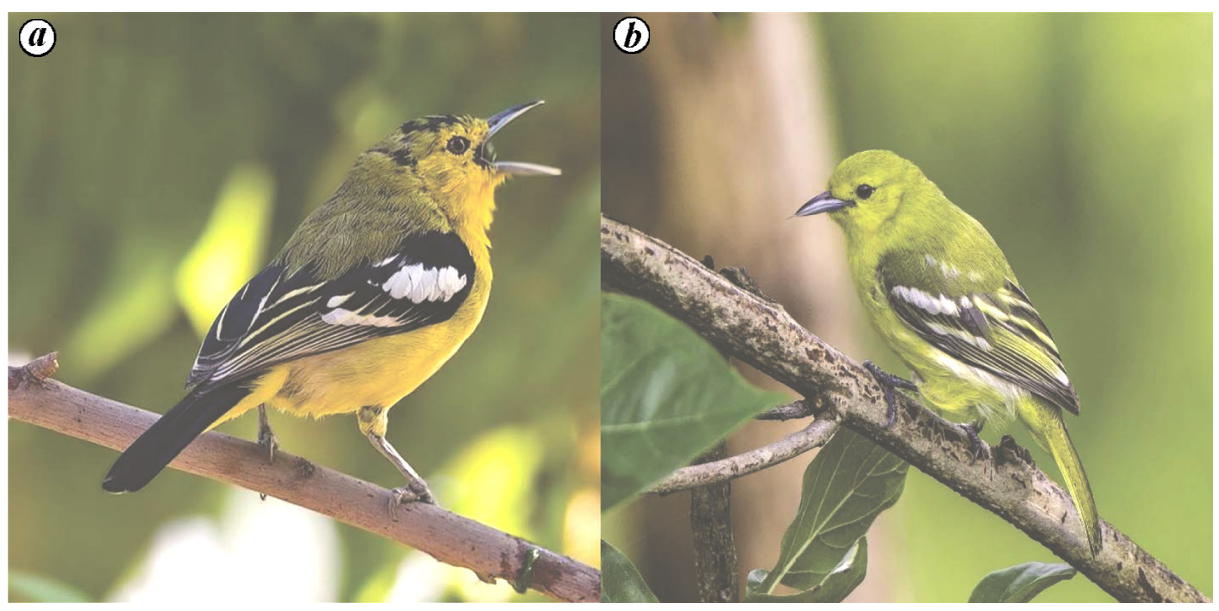

Figure 1. The study species. (a) Common Iora Aegithina tiphia male assuming breeding plumage and (b) female.

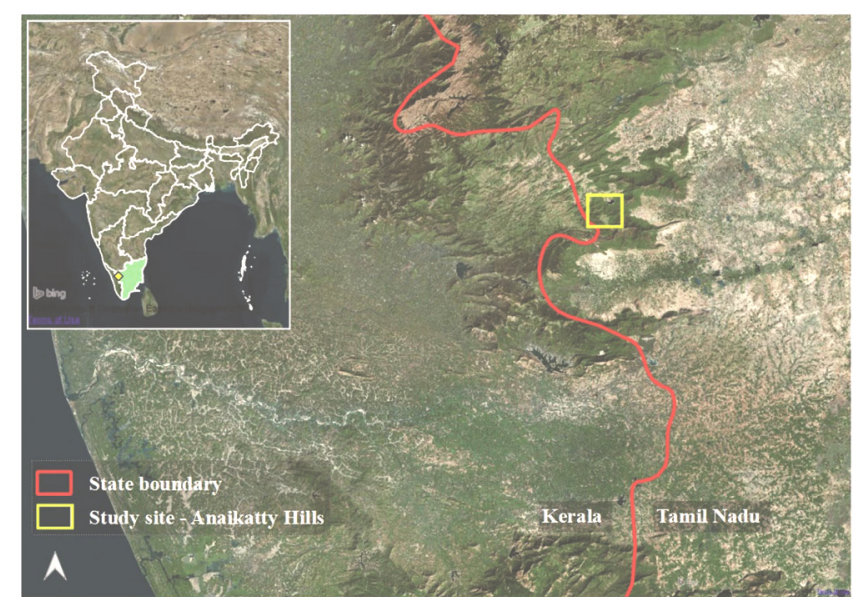

Figure 2. Study area. (Inset) Location of Anaikatty hills in India Map showing the study area with Tamil Nadu state boundary (Source: Bing Maps).

in biodiversity and forms a part of the Western Ghats, which is one among the 35 biodiversity hotspots of the world ${ }^{19}$. A total of 194 bird species from 45 families with $55 \%$ of passerine species has been reported from the study site ${ }^{20}$.

\section{Methods}

\section{Sound recording}

The study was conducted from March 2015 to October 2016. A continuous $5 \mathrm{~min}$ recording from four different locations of the study area was considered as a 'sampling unit'. Minimum of six replicas of sampling units were recorded from each of the locations. As the intention was not to compare between the locations of any specific pairs, opportunistic sampling of bird calls was done depending upon the availability of such calls in the loca- tions. However, the first author recorded the samples distributed throughout the day between 0600 and $1900 \mathrm{~h}$. The sampling units were distributed both in the breeding and non-breeding seasons.

Upon identifying a bird, the vocal communication was recorded using a portable linear audio recorder (Sony PCM-M10), with a condenser shotgun microphone (Audio-Technica ATR-6550) in .WAV format with $44.1 \mathrm{kHz}$ sampling frequency and 24 bit accuracy rate. The behaviour of the bird such as feeding, flying, hopping, perching during the vocalizations, presence and absence of the partner, perch height from the ground, bird presence in the tree or shrub and GPS coordinates, were simultaneously recorded.

\section{Data analyses}

From the 48 recordings comprising $240 \mathrm{~min}$ of song recordings, 142 vocalization events were extracted for further analysis.

\section{Spectrogram analysis}

The audio data were analysed using Raven Pro 1.4 (ref. 21) for the temporal and spectral features. The fundamental unit of the vocal signal is an 'element,' a steady streak or line on the spectrogram. Time variation and frequency range differences of a 'syllable' are expressed visually in a two-dimensional format on a spectrogram ${ }^{1,2}$. The frequency-time analysis measures the spectral features and their variation, including time duration, maximum and minimum frequencies as well as frequency range (maximum-minimum frequency). This information can be viewed by scrolling across the spectrographic display ${ }^{3,4}$. The spectrogram settings were as follows: Hann 512, $3 \mathrm{~dB}$ filter bandwidth $124 \mathrm{~Hz}, 50 \%$ overlap, grid spacing 86.1 Hz. Audacity 2.0.6 software $^{22}$ was used for making 
audio cuts for preparing the spectrogram. The frequency measurements were made on individual notes or on the entire call from the song sequence to interpret the spectral patterns ${ }^{4}$. The temporal and spectral features of the Common Iora syllables were measured by manual visual inspection method $^{5-9}$ and the following parameters were measured: start time, end time, delta time (time duration), low frequency, high frequency and delta frequency (frequency range).

\section{Delta time and frequency range}

Seven to ten replicates of the most common 15 syllables were considered and their respective start and end time $(\mathrm{sec})$ were physically marked on the spectrogram ${ }^{5-9}$. The delta time (time duration) value, i.e. difference between start and end time; and the delta frequency value, i.e. difference between high and low frequencies $(\mathrm{kHz})$ were analysed for studying the variation across 15 syllables $(n=142)$ using random effect in ANOVA test ${ }^{23}$. To identify any significance in the difference in high frequency across 15 syllables, ANOVA test was performed. These 15 syllables were compared along with their respective behaviour such as perching, feeding and hopping. The calling bird without a conspecific partner in a perch was referred as 'solitary', whereas the vocalizing individual along with a partner during feeding and hopping behaviour was presented as 'active'. Student's $t$-test was performed to check for significant difference of high frequency and delta time between the syllables of solitary males and the ones with conspecific partners ${ }^{24}$. All the above statistical tests were performed using SPSS ver.16 (ref. 25).

\section{Non-metric multidimensional scaling (NMDS) analysis}

Euclidean similarity index in three-dimensional NMDS was performed using PAST ver. 3.07 (ref. 26), to assess the similarities and dissimilarities among Common Iora syllables. The spectral and temporal parameters such as low frequency, high frequency, delta frequency and delta time of the 15 syllables were included in NMDS for grouping them against their respective behaviour and partner presence.

\section{Results}

\section{Syllable types}

There were 142 Common Iora vocalization events observed from 48 recordings collected in the study. The 15 most commonly uttered syllables were selected to study the spectral and temporal characteristics (Figure 3). Table 1 presents the associated behaviour noted while delivering these syllables. The Common Iora has short stereotyped calls where the male produces whistles, i.e. COIO IDs 1-12, 14 and 15 and the female exerts trills or rapid notes, i.e. COIO ID 13 (FM type). COIO IDs 6, 11, 12 and 14 have three elements and are known as trielemental syllables (Table 1). Whereas COIO IDs 10 and 15 have two elements and are known as di-elemental syllables (Table 1). The significant observations while considering the activity along with syllable delivery are: (i) birds repeated one syllable continuously during solitary perch, and (ii) they frequently changed syllables during activity (hopping, feeding) among foliage. Syllables COIO IDs 1-7 and 15 were uttered by solitary males when they had perched at a height of approx. 5-7 $\mathrm{m}$ on trees. While, syllables 8-12 and 14 were 'contact calls' performed by the birds along with conspecific partners in shrubs at a height within $2 \mathrm{~m}$ during feeding or hopping activity (Table 2). COIO IDs 12 and 13 were response syllables to their respective partners.

\section{Delta time and frequency range}

Figure 4 shows the median delta time of COIO syllables. The median delta time of syllable COIO IDs 1, 2, 5, 13 and 15 was longer than $1 \mathrm{sec}$, wherein the median values were $1.63 \mathrm{sec}(n=10$, range $=0.54-2.37 \mathrm{sec}), 1.84 \mathrm{sec}$ $(n=7, \quad$ range $=1.11-2.12 \mathrm{sec}), \quad 1.23 \mathrm{sec} \quad(n=10$, range $=0.76-1.55 \mathrm{sec}), 1.18 \mathrm{sec} \quad(n=10$, range $=0.40$ $2.16 \mathrm{sec})$ and $2.33 \mathrm{sec}(n=7$, range $2.23-2.48 \mathrm{sec})$ respectively. The remaining syllables were shorter than $1 \mathrm{sec}$, of which the shortest were COIO IDs 7 and 8 that lasted for $0.15 \mathrm{sec}(n=10$, range $=0.12-0.16 \mathrm{sec})$ and $0.15 \mathrm{sec}(n=10$, range $0.14-0.20 \mathrm{sec})$ respectively. The change in delta time significantly varied across 15 syllables (random effect in ANOVA, $F_{14,127}=70.41$, $p<0.0001)$. Also, outliers were observed in COIO IDs 1 , 11 and 14 that are placed above their delta time range as $0.54,0.92$ and $0.66 \mathrm{sec}$ respectively.

The mean low frequency ranged from 1300 to $2800 \mathrm{~Hz}$ and the mean high frequency from 2300 to $6700 \mathrm{~Hz}$. The female trills (rapid frequency variation) had extended frequency range between $1290 \mathrm{~Hz}$ and $6700 \mathrm{~Hz}$ (Figures 3 and 5). The frequency range of 13 syllables was below $2000 \mathrm{~Hz}$ (Figure 5) and for the syllable IDs 13 and 15, the median values were $5088 \mathrm{~Hz}(n=10$, range $=4155-$ $5859 \mathrm{~Hz})$ and $3399 \mathrm{~Hz}(n=7$, range $=3315-3398 \mathrm{~Hz})$ respectively. The syllable IDs $1,2,5$ and 6 were lower than $500 \mathrm{~Hz}$, wherein the median values were $293 \mathrm{~Hz}$ $(n=10$, range $=175-351 \mathrm{~Hz}), 455 \mathrm{~Hz} \quad(n=7$, range $=$ $290-628 \mathrm{~Hz}), 293 \mathrm{~Hz}(n=10$, range $=207-373 \mathrm{~Hz})$ and $419 \mathrm{~Hz}(n=10$, range $=410-539 \mathrm{~Hz})$ respectively. The change in frequency range also significantly varied across 15 syllables (random effect in ANOVA, $F_{14,127}=268.66$, $p<0.0001)$. The Pearson correlation between delta time and high frequency of Common Iora syllables showed a negative significance $(r=-0.286, p=0.002)$. The overall 

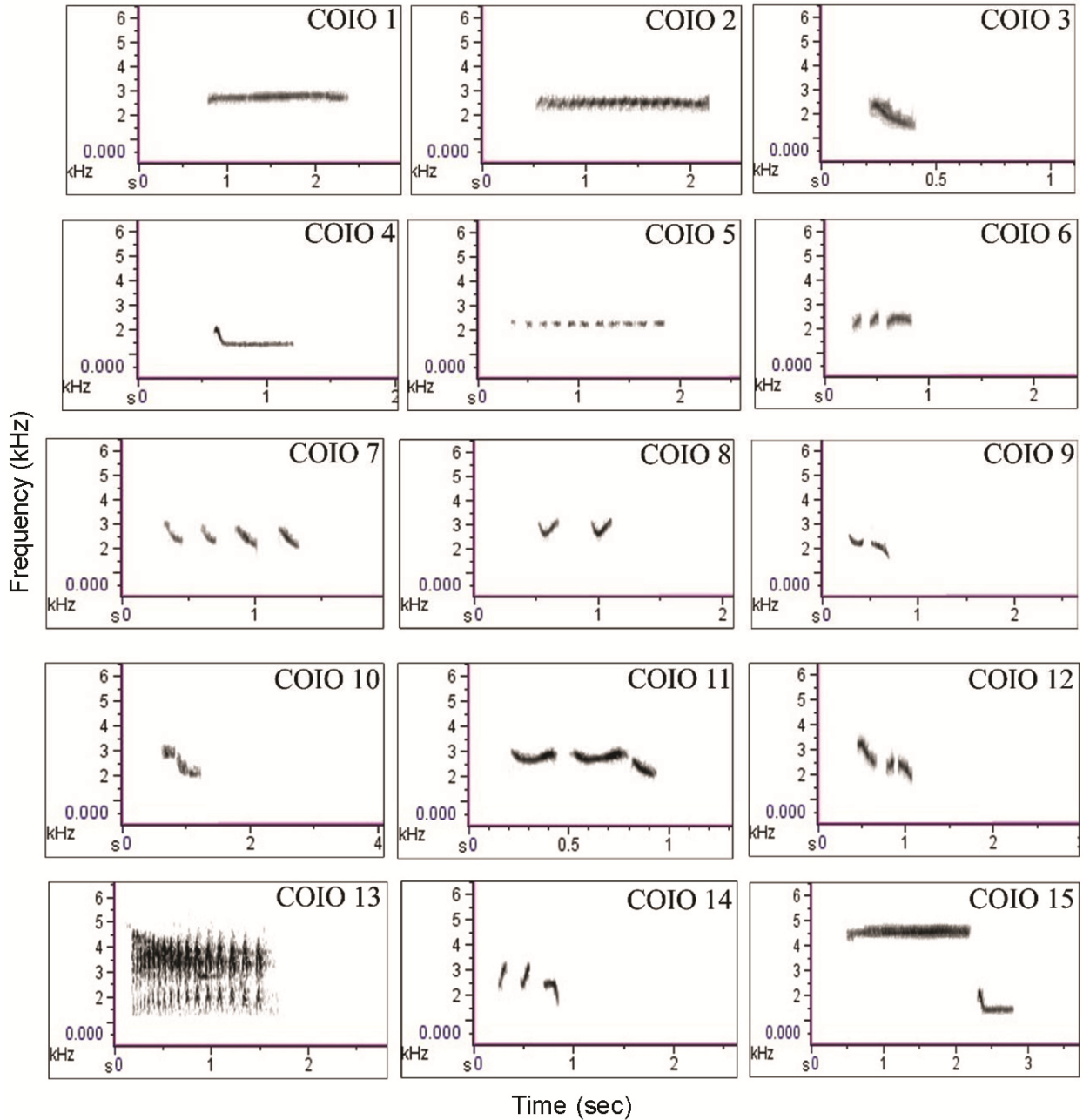

Figure 3. Common Iora syllable types (15 nos). Males produced wide variety of whistles and females produce trill (COIO ID $13(n=10))$ with male in proximity. COIO IDs $1(n=10), 2(n=7), 3(n=8)$, $4(n=10), 5(n=10), 6(n=10), 7(n=10)$ and $15(n=7)$ were performed by solitary male. COIO IDs $8(n=10), 9(n=10), 10(n=10), 11(n=10), 12(n=10)$ and $14(n=10)$ were pronounced by males in the proximity of females.

high frequency mean value was $3193 \pm 94.67_{\mathrm{SE}} \mathrm{Hz}$, which significantly varied with syllable type (ANOVA $\left.F_{14,127}=111.793, p<0.0001\right)$. There was a significant difference between mean low frequency values across the 15 syllable types (ANOVA $F_{14,127}=15.022, p<0.0001$ ), with a total low frequency mean value of $1853.08 \pm$ $473.25_{\mathrm{SE}}$. However, Pearson correlation explains no significant correlation between delta time and low frequency.

\section{Partner presence and call performance}

There was a significant difference in mean of high frequency between solitary male vocal signals $\left(2757 \pm 86.75_{\mathrm{SE}} \mathrm{Hz}\right)$ and vocal signals by male during partner presence $\left(3642 \pm 153.06_{\mathrm{SE}} \mathrm{Hz}\right)$ in Common Iora $(t=5.065, \mathrm{~d} f=$ $140, p<0.001$ ) (Figure $6 a$ and Table 1). Similarly, there was a significant difference in mean delta time between solitary male $\left(0.98 \pm 0.09_{\mathrm{SE}} \mathrm{Sec}\right)$ and syllables made by male in the presence of a partner $\left(0.63 \pm 0.04_{\mathrm{SE}} \mathrm{sec}\right)$ of Common Iora $(t=3.471, \mathrm{~d} f=140, p<0.001$; Figure $6 b)$. Males use different syllable types in these two different contexts (Table 1). For example, solitary male syllables (COIO IDs 1-7 and 15 (presented as M) were of low frequency and the syllables made during partner presence were of high frequency (COIO IDs 8-12 and 14; presented as $\mathrm{M}-\mathrm{P})$. COIO ID 13 was performed by female (F).

\section{Non-metric multidimensional scaling (NMDS) analysis}

The Euclidean similarity index in non-metric multidimensional scaling (NMDS; stress value 0.0001) showed a separate acoustic spacing of male and female syllables. The male syllables such as COIO IDs 1-12 and 14 get grouped together, in which the structurally simple syllables COIO IDs 1, 2, 5 and 6 with lesser frequency range 
RESEARCH ARTICLES

Table 1. Description of Common Iora syllables observed during the study period in Anaikatty hills, southern India

\begin{tabular}{|c|c|c|c|c|}
\hline COIO ID & $\begin{array}{l}\text { Physical characteristics } \\
\text { of the syllable }\end{array}$ & Definition & $\begin{array}{l}\text { Partner } \\
\text { presence }\end{array}$ & Context \\
\hline COIO 1 & Monotonic flat whistle & $\begin{array}{l}\text { A stretch of monotonic flat whistle made by male when perched at height } \sim 7 \mathrm{~m} \text {, } \\
\text { repeated continuously and gives a melancholy feel for the observer. }\end{array}$ & M & LDC \\
\hline COIO 2 & Whistle with FM* & $\begin{array}{l}\text { Frequency modulated (FM) whistle uttered by male at perch height } 6-7 \mathrm{~m} \text { in the } \\
\text { middle of the territory. It is also uttered when there is competition with other } \\
\text { males, at the boundary of the territory. Observed only during breeding season. }\end{array}$ & M & LDC \\
\hline COIO 3 & Whistle ending in lower frequency & $\begin{array}{l}\text { Whistle with a gradual drop in frequency, delivered during their inactive period at } \\
\text { perch height } 6 \mathrm{~m} \text { at the territory boundary. }\end{array}$ & M & LDC \\
\hline $\mathrm{COIO} 4$ & $\begin{array}{l}\text { Whistle dropping in frequency } \\
\text { with a drag }\end{array}$ & $\begin{array}{l}\text { Males perform this type of syllable continuously when perched in tree ( } 5 \mathrm{~m} \text { height) } \\
\text { during no activity, at territory boundary. The frequency drops initially and dragged } \\
\text { for about } 0.5 \mathrm{sec} \text {. }\end{array}$ & M & LDC \\
\hline COIO 5 & Short 8 consecutive flat whistles & $\begin{array}{l}\text { Male utters it during breeding season (March-July) in their territory and during } \\
\text { male-to-male vocal aggressive competition. Males repeat the same } \\
\text { syllable continuously ( } 8-10 \text { repeats) and changes to another syllable only } \\
\text { when the competitor gives up. }\end{array}$ & M & LDC \\
\hline COIO 6 & $\begin{array}{l}\text { Tri-elemental }{ }^{\#} \text { whistle with } \\
\text { frequency modulated } \\
\text { third element }\end{array}$ & $\begin{array}{l}\text { Syllable with frequency modulated third element. It is performed by male when } \\
\text { perched at } \sim 5 \mathrm{~m} \text { height. }\end{array}$ & M & LDC \\
\hline COIO 7 & Short 4 consecutive curvy whistles & $\begin{array}{l}\text { Syllable with a decrease in frequency and is seen in } 4 \text { repeats made mostly when } \\
\text { perched at } 4-5 \mathrm{~m} \text { height. }\end{array}$ & M & LDC \\
\hline COIO 8 & Frequency modulated whistle & $\begin{array}{l}\text { Syllable is uttered in single or as } 2 \text { repeats when they were actively hopping } \\
\text { in trees or shrubs along with females. }\end{array}$ & $\mathrm{M}-\mathrm{P}$ & $\mathrm{CC}$ \\
\hline COIO 9 & Di-elemental $^{\#}$ whistle with FM* & Females were seen around when male utter this frequency modulated whistle. & $\mathrm{M}-\mathrm{P}$ & $\mathrm{CC}$ \\
\hline COIO 10 & Di-elemental $^{\#}$ whistle & Male utter this syllable when they were active. Females were seen along with. & $\mathrm{M}-\mathrm{P}$ & $\mathrm{CC}$ \\
\hline COIO 11 & Tri-elemental ${ }^{\#}$ whistle with FM* & $\begin{array}{l}\text { Commonly uttered syllable by males and was mostly in repeats. Male duets } \\
\text { using this syllable. }\end{array}$ & $\mathrm{M}-\mathrm{P}$ & $\mathrm{CC}$ \\
\hline COIO 12 & Tri-elemental $^{\#}$ whistle with FM* & $\begin{array}{l}\text { 'pheeu-phe-pheu' - males utter during hopping and feeding on shrubs. } \\
\text { Female partner was seen along. The syllable has enthused quality. }\end{array}$ & $\mathrm{M}-\mathrm{P}$ & $\mathrm{CC}$ \\
\hline COIO 13 & Indistinct harsh phrase & $\begin{array}{l}\text { Female's indistinct harsh phrase noted during their hopping and feeding activity. } \\
\text { Female performs this in between their feeding action and male responds } \\
\text { about his presence. }\end{array}$ & $\mathrm{F}$ & $\mathrm{CC}$ \\
\hline COIO 14 & Tri-elemental ${ }^{\#}$ whistle with FM* & $\begin{array}{l}\text { Male performs this as a response to female syllable (COIO 13) during their } \\
\text { feeding activity. }\end{array}$ & $\mathrm{M}-\mathrm{P}$ & $\mathrm{CC}$ \\
\hline COIO 15 & Di-elemental $1^{\#}$ monotonic whistle & $\begin{array}{l}\text { Continuous repetition of this drowsy syllable occurs when males were } \\
\text { perched at height } \sim 7 \mathrm{~m} \text {, mostly in the centre of their territory. }\end{array}$ & M & LDC \\
\hline
\end{tabular}

$\mathrm{FM}^{*}$, Frequency modulated syllable. \#, Total number of elements. M, Syllable performed by 'solitary' male. M-P, Male syllable when partner is nearby. F, Syllable performed by female with male presence. LDC, Long distance calls and CC, Contact calls.

$(\sim 500 \mathrm{~Hz})$ are closely packed. The whistles COIO IDs 3, 4,7 and 9 are clubbed together. The syllables with similar median frequency range, viz. COIO IDs 10-12 and 14 (uttered by male in presence of partner) are grouped together, leaving COIO IDs 13 (female syllable) and 15 (with extended frequency range and delta time) in two separate clusters. The whistle COIO ID 8 is discretely spread in the NMDS, probably due to its widespread frequency range $(\sim 330-820 \mathrm{~Hz})$. Alternatively, COIO IDs 3, 4,7 and 9 with high frequency values $\sim 1200-3400 \mathrm{~Hz}$ occupy the upper region of the male syllable cluster. The precise classification based on positioning of the male bird and partner presence has not been observed (Figure 7).

\section{Discussion}

\section{Common Iora - a 'discontinuous singer'}

There was no observation of Common Iora vocalization during flight. Common Iora produces short syllables that were repeated and hence is categorized as 'discrete repertoire species" ${ }^{\prime 9}$. The stereotyped male whistles with 
Table 2. Frequency, time duration of Common Iora syllables and observed activity

\begin{tabular}{llcccc}
\hline $\begin{array}{l}\text { COIO } \\
\text { ID type }\end{array}$ & $\begin{array}{c}\text { Mean low } \\
\text { frequency }(\mathrm{Hz})\end{array}$ & $\begin{array}{c}\text { Mean high } \\
\text { frequency }(\mathrm{Hz})\end{array}$ & $\begin{array}{c}\text { Delta } \\
\text { frequency }(\mathrm{Hz})\end{array}$ & $\begin{array}{c}\text { Mean } \\
\text { delta time (sec) }\end{array}$ & Activity \\
\hline COIO 1 & $2065.07 \pm 348.89$ & $2362.64 \pm 3.89$ & $293.10 \pm 51.92$ & $1.646 \pm 0.489$ & Solitary \\
COIO 2 & $1340.15 \pm 234.45$ & $2591.49 \pm 2.59$ & $455.90 \pm 109.63$ & $1.749 \pm 0.379$ & Solitary \\
COIO 3 & $1928.44 \pm 980.88$ & $2788.54 \pm 9.74$ & $1046.00 \pm 119.60$ & $0.184 \pm 0.123$ & Solitary \\
COIO 4 & $2154.64 \pm 44.94$ & $2373.51 \pm 2.09$ & $1108.00 \pm 194.35$ & $0.496 \pm 0.153$ & Solitary \\
COIO 5 & $2028.49 \pm 100.35$ & $2611.29 \pm 1.04$ & $293.10 \pm 50.04$ & $1.203 \pm 0.224$ & Solitary \\
COIO 6 & $1738.2 \pm 131.33$ & $2469.86 \pm 5.54$ & $419.85 \pm 45.24$ & $0.555 \pm 0.039$ & Solitary \\
COIO 7 & $2452.25 \pm 262.78$ & $2731.46 \pm 1.49$ & $762.00 \pm 153.97$ & $0.147 \pm 0.016$ & Solitary \\
COIO 8 & $1586.76 \pm 222.4$ & $3288.21 \pm 8.17$ & $476.65 \pm 161.77$ & $0.161 \pm 0.024$ & Active \\
COIO 9 & $1590.82 \pm 208.95$ & $3036.13 \pm 3.94$ & $1553.00 \pm 357.44$ & $0.512 \pm 0.079$ & Active \\
COIO 10 & $1545.89 \pm 219.63$ & $3224.53 \pm 1.34$ & $1311.00 \pm 323.34$ & $0.571 \pm 0.062$ & Active \\
COIO 11 & $1842.63 \pm 315.35$ & $3133.28 \pm 2.02$ & $1195.00 \pm 397.06$ & $0.721 \pm 0.094$ & Active \\
COIO 12 & $1802.18 \pm 133.88$ & $3117.48 \pm 8.62$ & $1562.00 \pm 108.84$ & $0.637 \pm 0.084$ & Active \\
COIO 13 & $1290.77 \pm 122.51$ & $6686.45 \pm 4.97$ & $5088.00 \pm 459.19$ & $1.224 \pm 0.491$ & Active \\
COIO 14 & $2766.59 \pm 202.33$ & $3007.15 \pm 1.35$ & $1266.00 \pm 298.69$ & $0.589 \pm 0.034$ & Active \\
COIO 15 & $1683.02 \pm 44.31$ & $4653.94 \pm 3.13$ & $3399.00 \pm 44.31$ & $2.350 \pm 0.086$ & Solitary \\
\hline
\end{tabular}

COIO 1-12, 14 and 15 were male syllables and COIO 13 was uttered by females. The low frequency varies between 1300 and $2800 \mathrm{~Hz}$. The high frequency ranges between 2300 and $6700 \mathrm{~Hz}$. COIO ID 1 and 5 have lower frequency range $(293.10 \mathrm{~Hz})$. Female-uttered syllable COIO 13 has wide frequency range $(5088 \mathrm{~Hz})$.

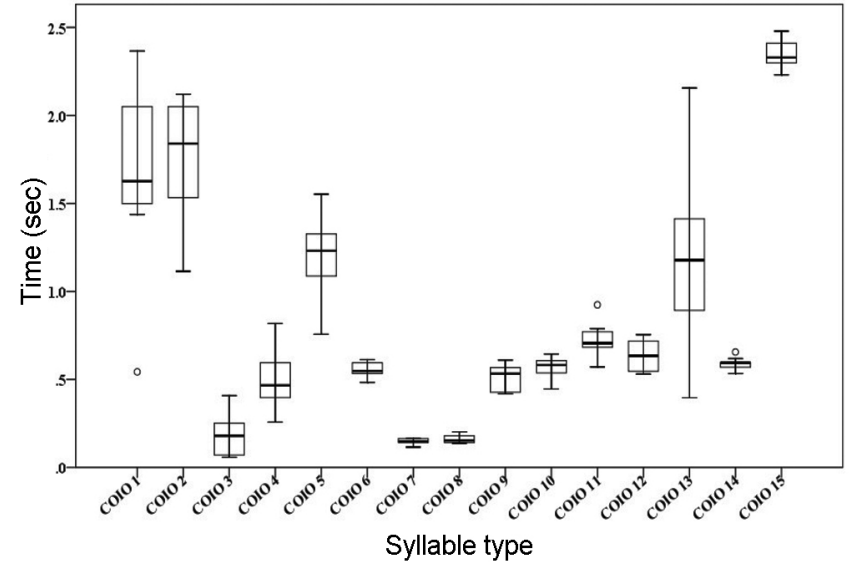

Figure 4. Time duration across 15 syllables. COIO IDs 1,2 and 13 occupy more time (sec) than other syllables. Female syllable COIO ID 13 has the maximum time duration with more variability in each utterance $(n=10)$. COIO IDs 7 and 8 maintain lesser time duration with lesser variability in each utterance.

less switching over between syllables recommend the species to be a 'discrete repertoire" or 'discontinuous singers ${ }^{27}$. The female note resembles tonal sounds with periodic FM that are expressed as rapid pitch variation and resembles a harsh, buzzy vocal signal ${ }^{1}$. Common Iora females produce trills (COIO ID 13) that occupy wider frequency bandwidth, which is contrary to male passerine birds producing trills ${ }^{28,29}$ that require precise coordination between the syrinx, vocal tract and frequency bandwidth. Rapid sequences of notes (or trills) which could be controlled by syringeal muscles through pulsatile expiration are uttered by budgerigars Melopsittacus undulates ${ }^{30}$ canaries Serinus canaria ${ }^{31}$ and northern cardinals Cardinalis cardinalis ${ }^{32}$.
Five of the six FM syllables were performed while the birds are active (Table 2) in the undergrowth and shrub. They have a rapid change in frequency within a short span of time and could result in possible dissipation, and hence, the bird produces lesser duration, high frequency syllables COIO IDs 6 and 7. Common Iora was observed feeding and hopping on trees and shrubs within $2 \mathrm{~m}$ height $^{17}$. The syllables COIO IDs 1-7 were exerted approx. $5 \mathrm{~m}$ above the ground (Table 1) and were heard from a long distance, i.e. from the centre and at the edges of the territorial boundary. These syllables were produced by solitary males possibly for long-range signal communication and termed as 'long distance' calls. Vocal signals are preferred to be uttered above the ground in order to lessen ground attenuation (fading of signals) and to decrease the impacts of vegetation, wind and temperature ${ }^{33}$.

Birds tend to avoid rapid FM signals when the habitat possesses signal scattering surfaces such as leaves and branches ${ }^{11,34,35}$. In this study also, rapid FM syllables COIO IDs 2, 6 and 7 were uttered in the open space on the upper canopy and hence, the species avoid dissipation of signals. However, similar positioning during song performance was not seen for FM syllables COIO IDs 11, 12 and 14 that were enunciated during partner presence. COIO IDs 8-14 were performed (during hopping or feeding) in the presence of conspecific partners and hence, signal transfer over longer distance was not required. These are 'contact calls' to communicate with conspecific partners.

\section{Song of Common Iora during partner presence}

Common Iora uses high frequency syllables in a shrub (foliage) with shorter delta time to communicate with the 


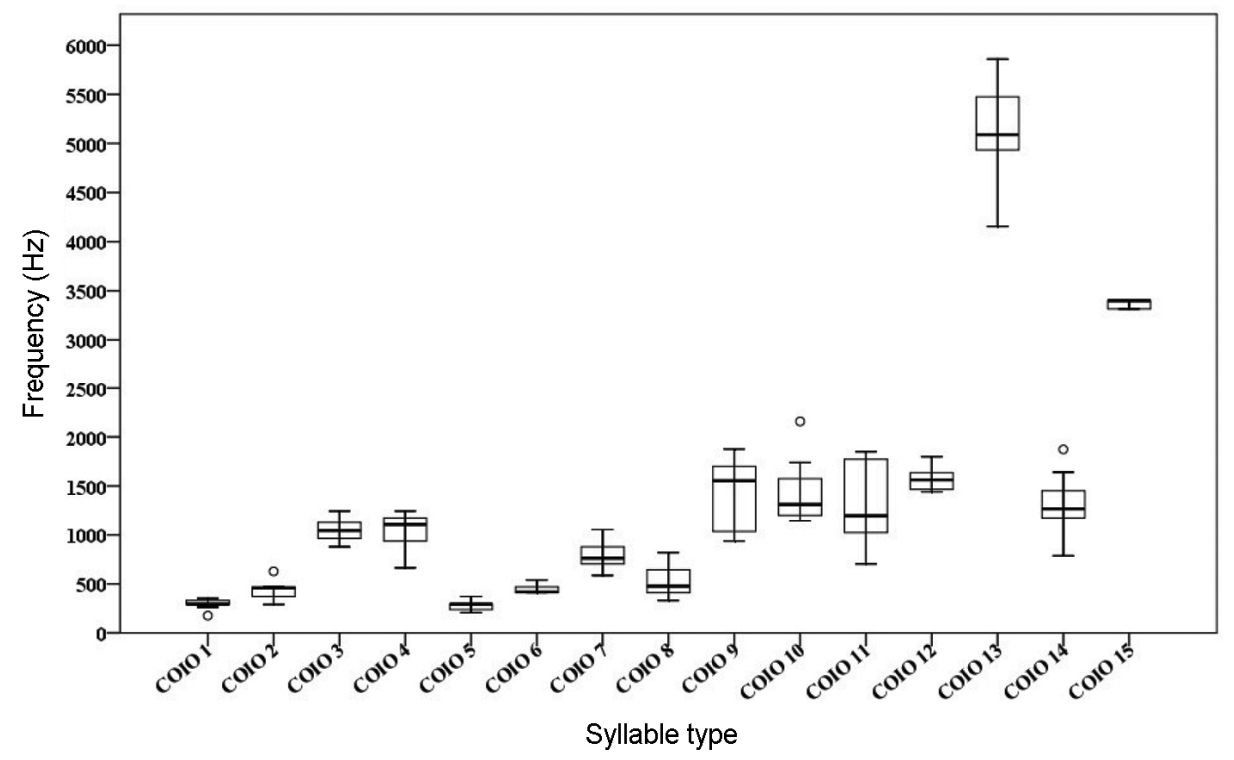

Figure 5. Frequency range of the 15 syllables. The frequency range is higher in COIO ID 13 (uttered by females) with more frequency modulation (FM) and higher variability in each utterance $(n=10)$. COIO IDs 1,5 and 6 remain with less frequency variation. COIO IDs 1-8 form the lower section of frequency bandwidth. COIO IDs 9-14 form the middle section and COIO IDs 13 and 15, the upper section of the frequency bandwidth respectively.
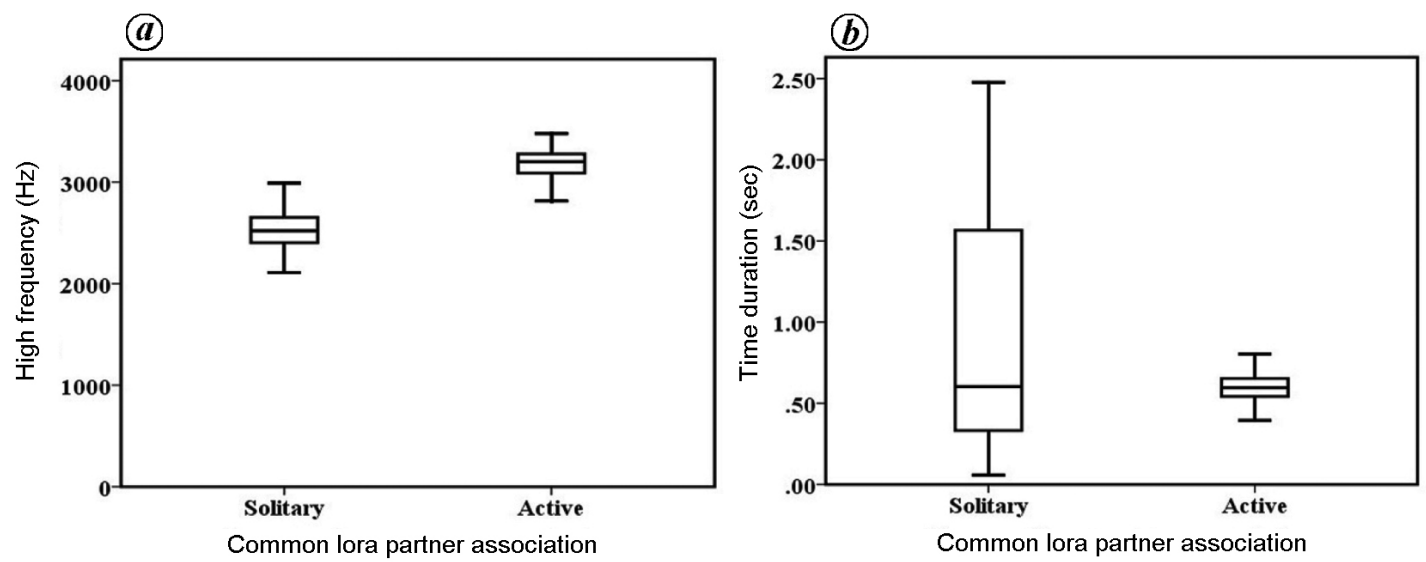

Figure 6. High frequency values and time duration of male syllables - a comparison of vocalization between solitary resting males and active males with partners. The syllables of males with partner in proximity have high frequency range and are of shorter duration, whereas those of solitary males have decreased high frequency values than active ones and can sustain for longer duration.

proximate partner. Though the higher frequency syllables get dissipated due to scattering effect through foliage than lower frequency syllables ${ }^{10,34,36}$, proximity of the partner makes dissipation insignificant. This suggests that context of the calls are more important than the loss of signal.

The syllables with low frequency values were pronounced at perch height of about 5-7 $\mathrm{m}$ by solitary males during breeding season. These syllables can travel more distance, probably to attract distant females. Wiley and Richards ${ }^{10}$ expounded that low frequency signals can travel the farthest regardless of habitat. The syllables uttered during rest/perch from a treetop are longer as it increases the chance of being heard by a distant female. Hence, these calls are probably intended for long distance communication.

\section{Conclusion}

Common Iora males produced 14 syllable types more commonly and females produced one syllable type during the study period. Males used high-frequency, short-duration syllables to communicate with their proximate partners. This could possibly be for preventing information dissipation and signal loss. Solitary males were observed 


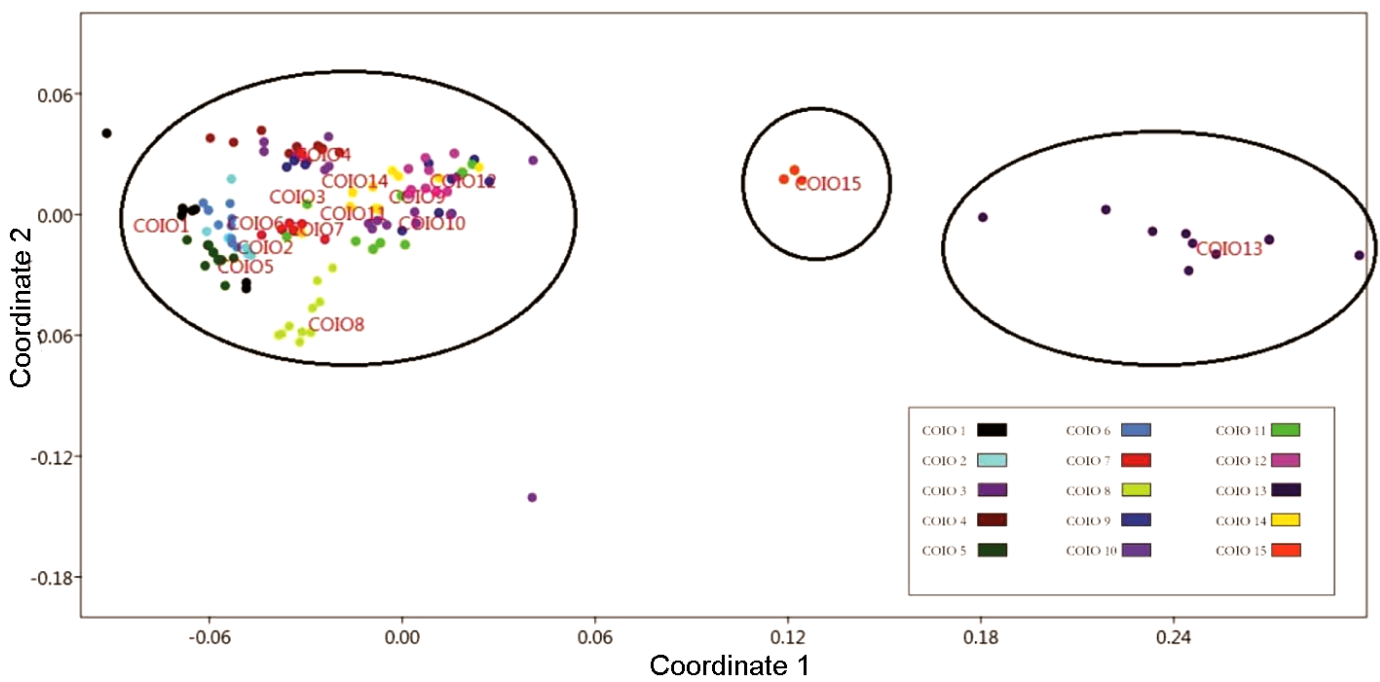

Figure 7. Non-metric multidimensional scaling (NMDS) plot using Euclidean similarity index. The three dimensional NMDS plot (stress: 0.0001324) shows three distinct clusters. Male Common Iora syllables COIO IDs 1-12 and 14 are clustered together. Female syllable COIO ID 13 branches as a separate pool (at the far right of the ellipse) and male syllable COIO ID 15 occupies a unique consortium.

to vocalize the low frequency syllables. These context preferences are not conclusive in nature based on this brief study, and it suggests existence of context specificity of spectral characteristics in bird vocalizations.

Competing interests: The authors declare that they have no competing interest.

1. Beeman, K., Digital signal analysis, editing, and synthesis. In Animal Acoustic Communication: Sound Analysis and Research Methods (eds Hopp, S. L., Owren, M. J. and Evans, C. S.), Springer Verlag, Berlin, Germany, 1998, pp. 59-103.

2. Catchpole, C. K. and Slater, P. J. B., Bird Song: Biological Themes and Variations, Cambridge University Press, Cambridge, UK, 2008, 2nd edn, pp. 203-239.

3. Beeman, K., RTS V1.0 User's Guide (IBM PC). Engineering Design, Belmont, Massachusetts, USA, 1991.

4. Beeman, K., RTS V2.0 User's Guide (IBM PC). Engineering Design, Belmont, Massachusetts, USA, 1996.

5. Cardoso, G. C. and Atwell, J. W., On the relation between loudness and increased song frequency of urban birds. Anim. Behav., 2011, 82, 831-836; https://doi.org/10.1016/j.anbehav.2011.07.018.

6. Singh, P. and Price, T. D., Causes of the latitudinal gradient in bird song complexity assessed from geographical variation within two Himalayan warbler species. Ibis, 2015, 157(3), 511-527; https://doi.org/10.1111/ibi.12271.

7. Nowicki, S. and Nelson, D. A., Defining natural categories in acoustic signals: comparison of three methods applied to 'chick-a-dee' call notes. Ethology, 1990, 86(2), 89-101; https://doi.org/10.1111/j.1439-0310.1990.tb00421.x.

8. Baker, M. C. and Boylan, J. T., A catalog of song syllables of Indigo and Lazuli Buntings. Condor, 1995, 97, 1028-1040.

9. Irwin, R. E., Directional sexual selection cannot explain variation in song repertoire size in the New World Blackbirds (Icterinae). Ethology, 1990, 85, 212-224; https://doi.org/10.1111/j.14390310.1990.tb00401.x.

10. Wiley, R. H. and Richards, D. G., Adaptations for acoustic communication in birds: sound propagation and signal detection. In
Acoustic Communication in Birds Vol. 1 (eds Kroodsma, D. E. and Miller, E. H.), Academic Press, New York, USA, 1982, pp. 131181.

11. Wiley, R. H., Associations of song properties with habitats for territorial oscine birds of eastern North America. Am. Nat., 1991, 138, 973-993; https://doi.org/10.1086/285263.

12. Morton, E. S., Ecological sources of selection on avian sounds. Am. Nat., 1975, 109(965), 17-34; https://doi.org/10.1086/282971.

13. Marten, K. and Marler, P., Sound transmission and its significance for animal vocalization. I. Temperate habitats. Behav. Ecol. Sociobiol., 1977, 2, 271-290; https://doi.org/10.1007/BF00299740.

14. Aylor, D., Noise reduction by vegetation and ground. $J$ Acoust. Soc. Am., 1971; 51(1), 197-205; https://doi.org/10.1121/1. $\underline{1912830 .}$.

15. Marten, K., Quine, D. and Marler, P., Sound transmission and its significance for animal vocalization. II Tropical forest habitats. Behav. Ecol. Sociobiol., 1977, 2, 291-302; https://doi.org/ 10.1007/BF00299741.

16. Ali, S. and Ripley, D., Handbook of the Birds of India and Pakistan Vol 6, Oxford University Press, 2001, 2nd edn.

17. Gokula, V. and Vijayan, L., Foraging pattern of birds during the breeding season in thorn forest of Mudumalai wildlife sanctuary, Tamil Nadu, southern India. Trop. Ecol., 2000, 41(2), 195-208.

18. Mukherjee, D. and Bhupathy, S., A new species of wolf snake (Serpentes: Colubridae: Lycodon) from Anaikatti hills, Western Ghats, Tamil Nadu, India. Russ. J. Herpetol., 2007, 14(1), 21-26.

19. Noss, R. F., Platt, W. J., Sorrie, B. A., Weakley, A. S., Means, D. B., Costanza, J. and Peet, R. K., How global biodiversity hotspots may go unrecognized: lessons from the North American Coastal Plain. Divers. Distrib., 2015, 21(2), 236-244.

20. Nirmala, T., Diversity of Avifauna in Anaikatty hills, Coimbatore. J. Biol. Food Sci. Res., 2013, 2(8), 97-108.

21. Bioacoustics Research Program, Raven Pro: Interactive Sound Analysis Software (Version 1.4), The Cornell Lab of Ornithology; Ithaca, NY, USA, 2011; http://www.birds.cornell.edu/raven.

22. Audacity Team, Audacity (version 2.0 .6 ; 2014) (computer program); http://audacityteam.org (retrieved on 24 December 2014).

23. Fisher, R. A., Statistical Methods for Research Workers, Oliver and Boyd, Edinburgh, UK, 1925.

24. Gosset, W. S., The probable error of a mean. Biometrika, 1908, 6(1), $1-25$. 
25. SPSS for Windows, Rel.16.0.0, SPSS Inc, Chicago, USA, 2007.

26. Hammer, Ø., Harper, D. A. T. and Ryan, P. D., PAST: paleontological statistics software package for education and data analysis. Palaeontol. Electron., 2001, 4(1), 1-9; http://palaeo-electronica. org/2001_1/past/issue1_01.htm.

27. Hartshorne, C., Born to Sing: An Interpretation and World Survey of Bird Song, Indiana University Press, 1973.

28. Ballentine, B., Hyman, J. and Nowicki, S., Vocal performance influences female response to male bird song: an experimental test. Behav Ecol., 2004, 15(1), 163-168; doi:10.1093/beheco/arg090.

29. Cramer, E. R. A., Physically challenging song traits, male quality, and reproductive success in house wrens. PLOS ONE, 2013, 8(3), e59208; https://doi.org/10.1371/journal.pone.0059208.

30. Suthers, R. A., Peripheral vocal mechanisms in birds: are songbirds special? Neth. J. Zool., 2001, 51(2), 217-242; https:// doi.org/10.1163/156854201X00288.

31. Hartley, R. S. and Suthers, R. A., Airflow and pressure during canary song: direct evidence for mini-breaths. J. Comp. Physiol. A, 1989, 165(1), 15-26; http://doi.org/10.1007/BF00613795.

32. Suthers, R. A. and Goller, F., Respiratory and syringeal dynamics of song production in northern cardinals. In Nervous Systems and Behaviour (ed. Burrows, M. et al.), Proceedings of the 4th International Congress of Neuroethology, Georg Thieme Verlag, Stuttgart, Germany, 1996, p. 333.

33. Endler, J. A., Signals, signal conditions, and the direction of evolution. Am. Nat., 1992, 139, S125-S153; https://doi.org/10.1086/ 285308.
34. Wiley, R. H. and Richards, D. G., Physical constraints on acoustic communication in the atmosphere: implications for the evolution of animal vocalizations. Behav. Ecol. Sociobiol., 1978, 3(1), 69 94; https://doi.org/10.1007/BF00300047.

35. Brenowitz, E. A., Environmental influences on acoustic and electric animal communication. Brain Behav. Evol., 1986, 28, 32-42; https://doi.org/10.1159/000118690.

36. Ryan, M. J. and Brenowitz, E. A., The role of body size, phylogeny, and ambient noise in the evolution of bird song. Am. Nat., 1985, 126, 87-100; https://doi.org/10.1086/284398.

ACKNOWLEDGEMENTS. We thank The Cornell Lab of Ornithology, NY, USA for providing RAVEN Pro 1.4 version with $100 \%$ concession, and the Director, Sálim Ali Centre for Ornithology and Natura History, Coimbatore for encouragement and providing the necessary facilities. We also thank the reviewers for comments on the earlier draft of the manuscript and Mr S. Jeevith (Sálim Ali Centre for Ornithology and Natural History, Coimbatore) for providing photographs of the Common Iora.

Received 25 September 2018; revised accepted 22 July 2019

doi: $10.18520 / \mathrm{cs} / \mathrm{v} 117 / \mathrm{i} 11 / 1863-1871$

\section{Errata}

\section{B. V. Sreekantan (1925-2019)}

\section{Palahalli R. Vishwanath}

[Curr. Sci., 2019, 117(10), 1740-1743]

Page 1741 Col 3 Para 2 lines 26, 27

should read as P. C. Agrawal and R. K. Manchanda

instead of G. S. Agrawal and Manchanda

Page 1741 Col 3 Para 2 last sentence

should read as 'Later Sreekantan and Naranan started rocket X-ray astronomy programme in 1970 and got interesting results.'

instead of 'Later Sreekantan and Naranan started rocket X-ray astronomy programme in 1970 and got interesting results from the payload on the first satellite (Aryabhata) itself.' 